Article

\title{
Cerium Oxide Nanoparticles: Synthesis and Characterization for Biosafe Applications
}

\author{
Prathima Prabhu Tumkur 1,2, Nithin Krisshna Gunasekaran 1,2, Babu R. Lamani ${ }^{3}$, Nicole Nazario Bayon ${ }^{1,2}$, \\ Krishnan Prabhakaran ${ }^{1}$, Joseph C. Hall ${ }^{1}$ and Govindarajan T. Ramesh ${ }^{1,2, *}$ \\ 1 Center for Biotechnology and Biomedical Sciences, Molecular Toxicology Laboratory, Norfolk State \\ University, 700 Park Avenue, Norfolk, VA 23504, USA; p.tumkur@spartans.nsu.edu (P.P.T.); \\ n.gunasekaran@spartans.nsu.edu (N.K.G.); n.m.nazario-bayon@spartans.nsu.edu (N.N.B.); \\ kprabhakaran@nsu.edu (K.P.); jchall@nsu.edu (J.C.H.) \\ 2 Center for Materials Research, Norfolk State University, 555 Park Avenue, Norfolk, VA 23504, USA \\ 3 Department of Bioinformatics and Biotechnology, Jnanashakthi Campus, Akkamahadevi Women's University, \\ Vijayapura 586108, Karnataka, India; baburl.rl@gmail.com \\ * Correspondence: gtramesh@nsu.edu; Tel.: +1-(757)-816-7176
}

\section{check for}

updates

Citation: Tumkur, P.P.; Gunasekaran, N.K.; Lamani, B.R.; Nazario Bayon, N.; Prabhakaran, K.; Hall, J.C.; Ramesh, G.T. Cerium Oxide Nanoparticles: Synthesis and Characterization for Biosafe Applications. Nanomanufacturing 2021, 1, 176-189. https://doi.org/ 10.3390/nanomanufacturing1030013

Academic Editor:

Ana María Díez-Pascual

Received: 25 August 2021

Accepted: 29 November 2021

Published: 3 December 2021

Publisher's Note: MDPI stays neutral with regard to jurisdictional claims in published maps and institutional affiliations.

Copyright: (c) 2021 by the authors. Licensee MDPI, Basel, Switzerland. This article is an open access article distributed under the terms and conditions of the Creative Commons Attribution (CC BY) license (https:/ / creativecommons.org/licenses/by/ $4.0 /)$.
Abstract: Due to its excellent physicochemical properties, cerium oxide $\left(\mathrm{CeO}_{2}\right)$ has attracted much attention in recent years. $\mathrm{CeO}_{2}$ nanomaterials (nanoceria) are widely being used, which has resulted in them getting released to the environment, and exposure to humans (mostly via inhalation) is a major concern. In the present study, $\mathrm{CeO}_{2}$ nanoparticles were synthesized by hydroxide-mediated method and were further characterized by Scanning Electron Microscopy (SEM), Field Emission Scanning Electron Microscopy (FESEM), Energy Dispersive X-ray Spectroscopy (EDX), Fourier Transform Infrared Spectroscopy (FTIR), and X-ray Diffraction Spectroscopy (XRD). Human lung epithelial (Beas-2B) cells were used to assess the cytotoxicity and biocompatibility activity of $\mathrm{CeO}_{2}$ nanoparticles. 3-(4,5-Dimethylthiazol-2-yl)-2,5-Diphenyltetrazolium Bromide (MTT) and Live/Dead assays were performed to determine the cytotoxicity and biocompatibility of $\mathrm{CeO}_{2}$ nanoparticles. Generation of reactive oxygen species (ROS) by cerium oxide nanoparticles was assessed by ROS assay. MTT assay and Live/Dead assays showed no significant induction of cell death even at higher concentrations $(100 \mu \mathrm{g}$ per $100 \mu \mathrm{L})$ upon exposure to Beas-2B cells. ROS assay revealed that $\mathrm{CeO}_{2}$ nanoparticles did not induce ROS that contribute to the oxidative stress and inflammation leading to various disease conditions. Thus, $\mathrm{CeO}_{2}$ nanoparticles could be used in various applications including biosensors, cancer therapy, catalytic converters, sunscreen, and drug delivery.

Keywords: cerium oxide nanoparticles; hydroxide-mediated method; microscopy; spectroscopy; cytotoxicity; biocompatibility; reactive oxygen species

\section{Introduction}

In nanotechnology, nanomaterials have been explored in various fields of science, such as physics [1], chemistry [2], biology [3], medicine [4], pharmacy [5], and materials sciences [6] because of their novel optical and electronic properties that differ from their bulk counterparts $[7,8]$. Nanomaterials are described as the elements with the diameter ranging from $1 \mathrm{~nm}$ to $100 \mathrm{~nm}$. Reduction in particle size enhances the properties of those particles [9]. The physical and chemical characteristics determine the main strength of the nanomaterials to be utilized in various applications [10]. Nanomaterials can be used for the development of new cutting-edge applications in communications, energy storage, sensing, data storage, optics, transmission, environmental protection, cosmetics, biology, and medicine [8]. Furthermore, significant efforts have been made to produce many nanoparticles/nanocrystals with controlled morphologies, shapes, and sizes in the past few years [8]. Examples of some nanoparticles that are currently being explored are cerium, cellulose, silver, titanium, iron, aluminum, manganese, tantalum, gold, or a mixture of at least two thereof. 
Of all the above nanoparticles, cerium is the first element in the lanthanide series which belongs to the rare earth family [11]. Cerium integrates with oxygen during the formation of cerium oxide nanoparticles; they acquire a fluorite structure [12]. Cerium oxide exists in 3+ and 4+ states, and redox cycling between cerium in these two states is the reason for the antioxidant properties [13]. Due to the significance of oxygen vacancies in cerium oxide, they can act as solid electrolyte in fuel cells [8]. The cerium oxide nanoparticles have got a significant consideration from the researchers in the field of nanotechnology because of their applications as catalyst converters, fuel additives and self-regenerating antioxidants [14].

Nanoceria has been found to possess great potential for a broad range of applications, particularly in the biomedical field. Nanoceria has been found to exert a profound antibacterial effect against different strains of bacteria. The usefulness of nanoceria depends upon its inherent property of showing variable oxidation states, due to which it can act as an excellent antioxidant agent and protect the healthy cells from oxidative stress [15]. Further, cerium oxide nanoparticles have been reported to act as synthetic antioxidant catalysts with measurable CNS penetrance, prolonged retention in the CNS, and high, regenerative catalytic activity that hold great promise for use in MS patients and, potentially, other ROS mediated disorders of the CNS [16].

Various methods used for the synthesis of cerium oxide nanoparticles include hydrothermal method, solvo-thermal method, and micro emulsification method [12]. Properties of nanomaterials determine the characterization techniques to be used to make sure that these techniques are sufficient to provide necessary information regarding those properties $[17,18]$. Parameters like size and morphology are analyzed by the means of microscope-based characterization methods. Parameters like crystal structure and elemental composition are determined by scattering and spectroscopy-based characterization techniques [17]. These methods help to determine the use of cerium oxide nanoparticles in various applications like low-temperature water-gas shift (WGS) reaction [19]; autoexhaust catalyst [20]; fuel cells [21]; oxygen sensors [22]; glass-polishing materials [23]; oxygen permeation membrane systems [24]; electrochromic thin-film application [25]; as well as environmental chemistry, biotechnology, and medicine [26,27].

$\mathrm{CeO}_{2}$ nanomaterials are widely being used which has resulted in them getting released into the environment and exposure to humans (mostly via inhalation) is a major concern. Currently many publications are focused on mechanistic studies and potential therapeutic uses of $\mathrm{CeO}_{2}$ nanoparticles. Insufficient toxicity and biocompatibility data is available on $\mathrm{CeO}_{2}$ nanoparticles to support its biosafety [28]. Interactions between nanomaterials and living systems, including humans, may potentially have harmful effects [10]. For this reason, the nanomaterials must be assessed for toxicity and biocompatibility aspects. Results found in the publications reporting the toxicity of $\mathrm{CeO}_{2}$ nanomaterials are contradictory. Low toxicity and inflammation effects of $\mathrm{CeO}_{2}$ nanomaterials were reported in some publications [29-31]. On the contrary, toxic effects of $\mathrm{CeO}_{2}$ nanomaterials triggering cell death was also reported [32]. The cause of toxic effect was found to be reactive oxygen species (ROS) generation which can damage the cell and ultimately lead to activation of cell death [32]. Some papers reported that $\mathrm{CeO}_{2}$ nanomaterials induce oxidative stress both in vitro and in vivo whereas they also act as direct antioxidants and behave as free radical scavengers [33]. Findings have also shown $\mathrm{CeO}_{2}$ nanomaterials to exhibit either antioxidant properties or pro-oxidative properties [34-36].

In the present study, a hydroxide-mediated approach was used to synthesize the cerium oxide nanoparticles $\left(\mathrm{CeO}_{2}-\mathrm{NP}\right)$ and the characterization methods such as Scanning Electron Microscopy (SEM), Field Emission Scanning Electron Microscopy (FESEM), Energy Dispersive X-ray Spectroscopy (EDX), Fourier Transform Infrared Spectroscopy (FTIR), and X-ray Diffraction Spectroscopy (XRD) were used to analyze the properties of the cerium oxide nanoparticles. Later, $\mathrm{CeO}_{2}$ nanoparticles were assessed for toxicity and biocompatibility studies by 3-(4,5-dimethylthiazol-2-yl)-2,5-diphenyltetrazolium bromide (MTT), Live/Dead, and Reactive Oxygen Species (ROS) assays. 


\section{Materials and Methods}

\subsection{Materials}

Cerium (III) nitrate hexahydrate and sodium hydroxide known by their chemical formulas, $\mathrm{Ce}\left(\mathrm{NO}_{3}\right)_{3} \bullet 6 \mathrm{H}_{2} \mathrm{O}$ and $\mathrm{NaOH}$, respectively, were the primary chemical compounds used for the synthesis of cerium oxide nanoparticles. These compounds were purchased from Thermo Fischer Scientific (Rockford, IL, USA). Dulbecco's Modified Eagle's Medium (DMEM), Dulbecco's Phosphate-Buffered Saline (DPBS) solution, Fetal Bovine Serum (FBS), penicillin, and streptomycin were obtained from Atlanta Biologicals, Inc. (Atlanta, GA, USA). Single-Wall Carbon Nanotubes (SWCNTs), 3-(4,5-dimethylthiozol-2-yl)-2,5-diphenyl tetrazolium bromide (MTT), dimethyl sulf-oxide (DMSO), and 2',7'-Dichlorofluorescin Diacetate (DCF-DA) were purchased from Sigma Aldrich (St. Louis, MO, USA). Live/Dead assay kit was obtained from Thermo Fischer Scientific (Rockford, IL, USA). Human lung epithelial cell line (Beas-2B) was procured from American Type Culture Collection (Manassas, VA, USA).

\subsection{Synthesis of Cerium Oxide Nanoparticles}

The synthesis process was carried out using hydroxide-mediated approach which is dominant over other methods in such a way that uniform distribution of particle size can be achieved $[37,38]$. A solution $(0.1 \mathrm{M})$ of cerium nitrate hexahydrate and $0.3 \mathrm{M}$ solution of sodium hydroxide were prepared by diluting those compounds with $200 \mathrm{~mL}$ of deionized water in two separate $250 \mathrm{~mL}$ beakers.

A clean burette was set up in the burette stand. A magnetic stirrer was placed under the burette and the beaker with $0.1 \mathrm{M}$ solution of cerium nitrate hexahydrate was placed on the magnetic stirrer to maintain constant stirring of the solution. The $0.3 \mathrm{M}$ solution of sodium hydroxide was taken in the burette and dripped into the $\mathrm{Ce}\left(\mathrm{NO}_{3}\right)_{3} \bullet \mathrm{H}_{2} \mathrm{O}$ solution placed below the burette.

At the end of the process, the solution was obtained with precipitate which was then centrifuged for $15 \mathrm{~min}$ at $8000 \mathrm{rpm}$ to get the precipitate to settle down at the bottom. The supernatant was discarded, and the precipitate was further washed thrice with water and once with ethanol and isopropanol.

After this process, the precipitate was collected in a glass plate and dried in a hot air vacuum oven at the temperature of $200^{\circ} \mathrm{C}$. At the end of this process, mortar and pestle was used to crush the dried precipitate into fine particles.

\subsection{Characterization Techniques}

\subsubsection{Scanning Electron Microscopy}

Phenom G2 Pro Tabletop SEM (Phenom, FEI Company, Hillsboro, OR, USA) was used to perform the scanning electron microscopy analysis. SEM is a multipurpose instrument which is able to provide qualitative information of the material including its morphology, topography, composition, and crystallographic information [9]. To prepare the sample for SEM, a double sided carbon adhesive tape was cut for the required shape and the side with exposed adhesive was adhered to the specimen holder and the other side has a thin layer of liner on the top. A small amount of cerium oxide nanoparticles was dissolved with ethanol and sonicated for uniform dispersion of nanoparticles in ethanol. Immediately after sonication, the top layer of liner in the tape was removed and $10 \mu \mathrm{L}$ of the sonicated solution was pipetted on the adhesive part of the specimen holder. The sample was dried and was loaded in the equipment to start the SEM analysis.

\subsubsection{Field Emission Scanning Electron Microscopy}

Characterization of nanoparticles using Field Emission Scanning Electron Microscopy is carried out using Hitachi S-4700 Field Emission Scanning Electron Microscope (Hitachi, Chiyoda, Tokyo, Japan) with Energy Dispersive X-ray Spectroscopy. Sample was prepared [39] and loaded and a vacuum environment was created to confirm the absence of any air molecules in the microscope. The primary electrons released from field emission 
source were focused on the sample, and as a result secondary electrons were discharged from the sample which generates signals and those signals were converted into images to perform the further analysis. FESEM is advantageous over SEM in such a way that the source of electrons being a sharp field emission gun generates elevated resolution images with low acceleration voltages [40].

The elemental composition of cerium oxide nanoparticles was determined by Energy Dispersive X-ray Spectroscopy (Phenom, FEI Company, Hillsboro, OR, USA). The energy dispersive spectrometer records the characteristic $X$-ray which determines the composition of elements in cerium oxide nanoparticles along with the concentration of those elements [40].

\subsubsection{Fourier Transform Infrared Spectroscopy}

FTIR spectroscopy is a significant method for determining the presence of compounds. The nanoparticles sample was subjected to irradiation from which the presence of functional groups and the presence of respective compound in the fingerprint region are identified along with the intensity of their stretching bands [41]. These obtained intensities were plotted to their respective wavenumbers in the FTIR spectrum. Fourier Transform Infrared Spectroscopy was carried out using the equipment called Nicolet Nexus 670 (Nicolet instruments, Madison, WI, USA) which was set in absorbance mode in the range of $650 \mathrm{~cm}^{-1}$ to $4000 \mathrm{~cm}^{-1}$ to analyze the nanoparticles with multiple number of scans.

\subsubsection{X-ray Diffraction Spectroscopy}

XRD (Panalytical Empyrean, Malvern Panalytical, Malvern, United Kingdom) was used for determining and analyzing the crystal structure of the cerium oxide nanoparticles. Preparation of sample for XRD is simple compared to other methods. The sample holder had a well in which the synthesized nanoparticles were filled. Extra powders were removed by using a glass slide which also makes the surface even. The sample was then analyzed using the X-rays with the source of $\mathrm{Cu} \mathrm{K} \alpha$ having the wavelength of $1.5418 \AA$ to determine the crystal structure and phase composition of those particles which provides a diffraction pattern from $20^{\circ}$ to $80^{\circ}$ in the series of $2 \theta$ [42].

\subsection{In Vitro Cell Culture and Experimental Conditions}

Beas-2B is a non-tumorigenic human lung epithelial cell line which was immortalized via transfection with an adenovirus 12-SV40 hybrid virus. However, recent investigations revealed that those cells exhibit characteristics of mesenchymal stem cells [43].

Beas-2B was cultured in DMEM media containing $4500 \mathrm{mg} / \mathrm{L}$ D-glucose, L-glutamine, and sodium pyruvate supplemented with 10\% fetal bovine serum (FBS), $1 \% 100 \mathrm{IU} / \mathrm{mL}$ of penicillin, and $100 \mathrm{~g} / \mathrm{mL}$ of streptomycin and incubated at $37{ }^{\circ} \mathrm{C}$ in a $\mathrm{CO}_{2}$ incubator with $5 \% \mathrm{CO}_{2}$ and $95 \%$ humidified atmosphere for at least $24 \mathrm{~h}$. before the appropriate treatments. In this study, cerium oxide nanoparticles and SWCNTs stock solutions were prepared in the cell culture medium (DMEM) and required concentrations was added to the wells to perform all experiments. In the control experiments, cells without nanoparticles were considered as negative control and cells treated with SWCNTs were considered as positive control.

\subsection{Measurement of Cell Viability by MTT Assay}

The effect of cerium oxide nanoparticles on cell viability was assessed by using a yellow tetrazolium salt, MTT, as described earlier with slight modification [44]. Cerium oxide nanoparticles were prepared at selected concentrations $(10,25,50$, and $100 \mu \mathrm{g})$ in $100 \mu \mathrm{L}$ supplemented DMEM and were homogenized. Beas-2B cells suspension was seeded in a 96-well microplate (at 5000 cells/well), in $100 \mu \mathrm{L}$ of supplemented DMEM and incubated for $48 \mathrm{~h}$ at $37{ }^{\circ} \mathrm{C}$ under a $5 \% \mathrm{CO}_{2}$ atmosphere. Then, medium was discarded, and washed with DPBS. $100 \mu \mathrm{L}$ of varying concentrations of cerium oxide nanoparticles test solutions were added to the cell culture and incubated at $37{ }^{\circ} \mathrm{C}, 5 \% \mathrm{CO}_{2}$ for $48 \mathrm{~h}$ 
$100 \mu \mathrm{L}$ of a negative control (cells without nanoparticles) and a positive control (25 $\mu \mathrm{g}$ of SWCNTs in supplemented DMEM) were also tested. Each treatment was performed 6 times independently. Thereafter, the supernatant was removed and $100 \mu \mathrm{L}$ of MTT solution (125 $\mu \mathrm{g} /$ well in DMEM supplemented) was added to each well and placed in a $5 \% \mathrm{CO}_{2}$ incubator at $37^{\circ} \mathrm{C}$ for $3 \mathrm{~h}$, to allow the formation of purple formazan crystal. Afterward, the medium was discarded, and purple formazan crystals formed inside the cells were solubilized using $100 \mu \mathrm{L}$ of DMSO. The culture plates were placed on a rocker for $30 \mathrm{~min}$ to completely solubilize purple formazan crystals. The enzymatic reduction of yellow tetrazolium dye, MTT to a purple formazan is catalyzed by mitochondrial succinate dehydrogenase [45] which was measured by a Multi-mode Microplate Reader (FLUOstar Omega, BMG Labtech, Ortenberg, Germany) at $570 \mathrm{~nm}$.

\subsection{Live/Dead Cell Imaging Assay}

To assess and reconfirm the cell viability and cytotoxicity of cerium oxide nanoparticles with MTT assay results, a two-color assay, Live/Dead cell imaging kit was used [39]. This assay helps to distinguish between live and dead cells with the help of non-fluorescent cell-permeable dye (calcein AM) for staining of live cells and cell-impermeable dye (ethidium homodimer-1) for staining of dead and dying cells. Calcein-AM gets converted to green-fluorescent dye to indicate intracellular esterase activity in a live cell and ethidium homodimer- 1 binds to nucleic acids to produce enhanced red fluorescence to indicate loss of plasma membrane integrity in a dead cell [46].

Beas-2B cells suspension was seeded in a 6-well microplate (at 10,000 cells/well) in $2 \mathrm{~mL}$ of supplemented DMEM and incubated for $48 \mathrm{~h}$ at $37^{\circ} \mathrm{C}$ under a $5 \% \mathrm{CO}_{2}$ atmosphere. Then, medium was discarded, and washed with DPBS. Cerium oxide nanoparticles (10, 25, 50, and $100 \mu \mathrm{g}$ ) test solutions prepared in $2 \mathrm{~mL}$ supplemented DMEM were added to the cell culture and incubated at $37^{\circ} \mathrm{C}, 5 \% \mathrm{CO}_{2}$ for $48 \mathrm{~h} 2 \mathrm{~mL}$ of a negative control (cells without nanoparticles) and a positive control ( $25 \mu \mathrm{g}$ of SWCNTs in supplemented DMEM) were also tested. Each treatment was performed 6 times independently. Then, the supernatant was removed and a dye mixture containing $4 \mu \mathrm{M}$ ethidium homodimer and $2 \mu \mathrm{M}$ calcein-AM was prepared by adding $20 \mu \mathrm{L}$ of the $2 \mathrm{mM}$ EthD-1 stock solution and $5 \mu \mathrm{L}$ of the supplied $4 \mathrm{mM}$ calcein AM stock solution to $10 \mathrm{~mL}$ of sterile DPBS. $2 \mathrm{~mL}$ of the dye mixture was added to the each well and incubated for $30 \mathrm{~min}$ at room temperature. After incubation, the green and red color-stained cells were observed under a fluorescence microscope (Nis Element, Nikon Instruments Inc, Melville, NY, USA) at an excitation (ex)/emission (em) $495 \mathrm{~nm} / 515 \mathrm{~nm}$ and at an ex/em $495 \mathrm{~nm} / 635 \mathrm{~nm}$, respectively and the image of each well was captured.

\subsection{Detection of Reactive Oxygen Species by ROS Assay}

The levels of intracellular reactive oxygen species (ROS) activity within the Beas-2B cells in the presence of cerium oxide nanoparticles were measured using the ROS assay as described earlier [39]. The assay uses a cell permeable compound, DCF-DA which after diffusion into the cells is deacetylated by cellular esterases to a non-fluorescent compound, and later oxidized by ROS into a highly fluorescent molecule, $2^{\prime}, 7^{\prime}$-dichlorofluorescin (DCF) [47].

Beas-2B cells suspension was seeded in a black 96 -well microplate (at 10,000 cells/well), in $100 \mu \mathrm{L}$ of supplemented DMEM and incubated for $48 \mathrm{~h}$ at $37^{\circ} \mathrm{C}$ under a $5 \% \mathrm{CO}_{2}$ atmosphere. Ten microliters of $10 \mu \mathrm{M}$ DCF-DA was added to the cultured cells and incubated in the chamber for $3 \mathrm{~h}$. The cells were then washed with DPBS and treated with $100 \mu \mathrm{L}$ of different concentration of cerium oxide nanoparticles $(5,10,25,50$, and $100 \mu \mathrm{g})$ dispersed in supplemented DMEM. After $48 \mathrm{~h}$, the intensity of fluorescence was measured at excitation/emission wavelength of $485 / 527 \mathrm{~nm}$, respectively, and the values represent the fluorescence unit. 


\section{Results and Discussion}

\subsection{Synthesis}

The cerium oxide nanoparticles were successfully synthesized using the hydroxide mediated approach and yellowish white nanoparticles were obtained. This is one of the simple and economic method to synthesize the cerium oxide nanoparticles. Cerium nitrate hexahydrate is one of the significant precursors used in several synthesis methods. In hydroxide-mediated approach, cerium nitrate hexahydrate is dissolved in deionized water to get a homogeneous solution through which the conversion of $\mathrm{Ce}^{3+}$ state to $\mathrm{Ce}^{4+}$ state takes place which then gets reacted with sodium hydroxide to synthesize the cerium oxide nanoparticles [48].

\subsection{Characterization}

The cerium oxide nanoparticles synthesized by hydroxide mediated approach were characterized by various methods such as SEM, FESEM, EDX, FTIR, XRD, and the results of these methods are discussed here.

\subsubsection{SEM Analysis}

The cerium oxide nanoparticles were analyzed through Scanning Electron Microscope and as a result, the image with cluster of uniformly distributed particles was obtained as shown in the Figure 1. On measuring the nanoparticles using the image J software, the average size of the particles obtained was in the range of $40 \mathrm{~nm}$ to $50 \mathrm{~nm}$ thereby confirming the existence of nanoparticles.

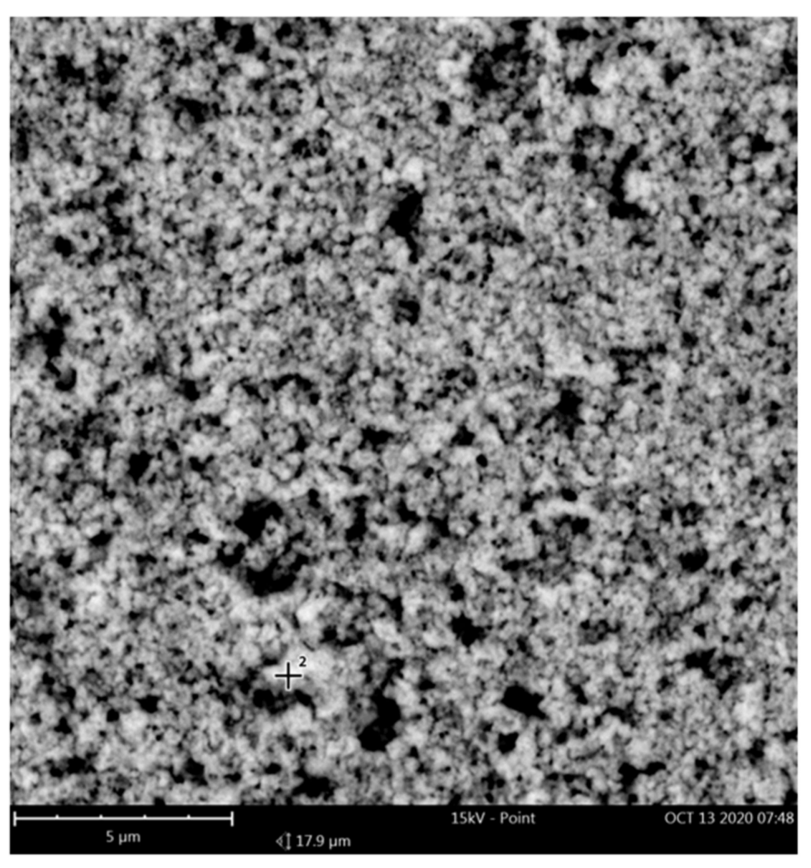

Figure 1. Scanning Electron Microscopy (SEM) image representing the particle distribution of cerium oxide nanoparticles.

\subsubsection{FESEM-EDX Analysis}

The cerium oxide nanoparticles were characterized by Field Emission Scanning Electron Microscopy to obtain a more elevated image to determine if there are particles with decreased size as compared to the one obtained in SEM. The image as shown in the Figure 2 obtained was analyzed and as a result, the average size of the nanoparticles was found to be between $10 \mathrm{~nm}$ and $30 \mathrm{~nm}$. 


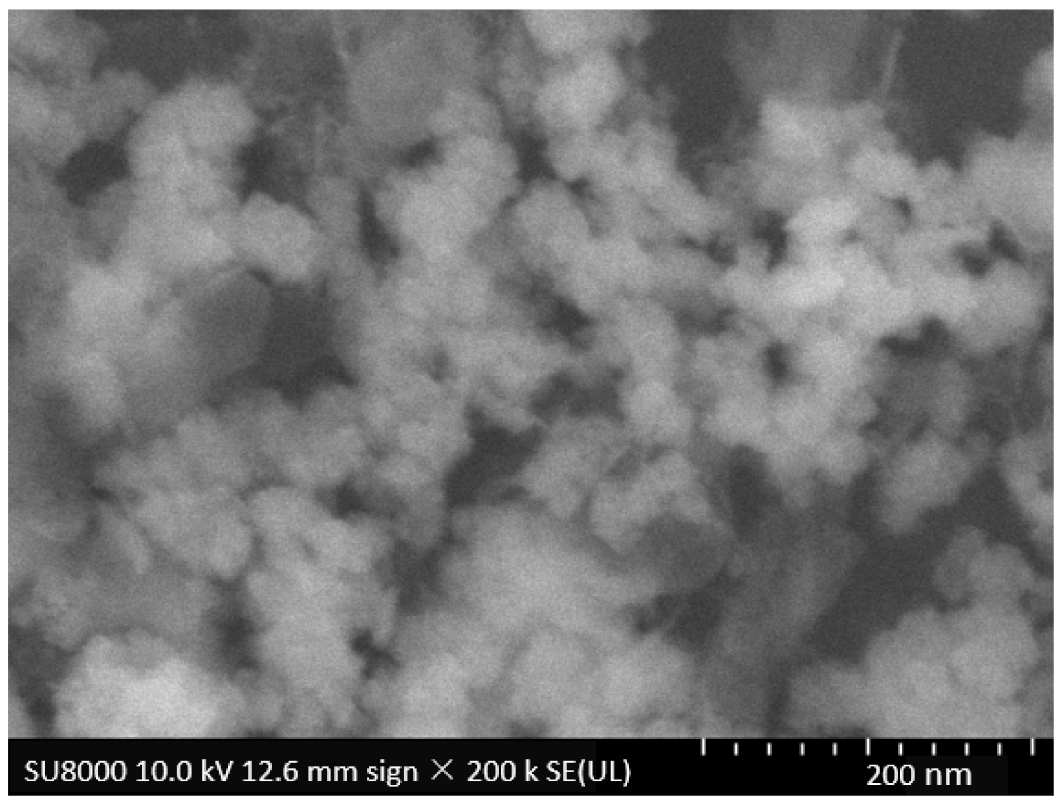

Figure 2. Field Emission Scanning Electron Microscopy (FESEM) image representing the particle distribution of cerium oxide nanoparticles. Reproduced with permission of [49]. Copyright SPIE conference, 2016.

After obtaining the image from FESEM analysis, the sample was subjected to Energy Dispersive X-ray Spectroscopy where the elemental composition of the cerium oxide nanoparticles along with their weight concentration was determined as shown in the Figure 3. It is evident from the EDX spectrum that cerium and oxygen are present making sure that the obtained cerium oxide nanoparticles are almost pure which is assured by the weight concentration of cerium and oxygen which accounts to a total of $99.8 \%$.

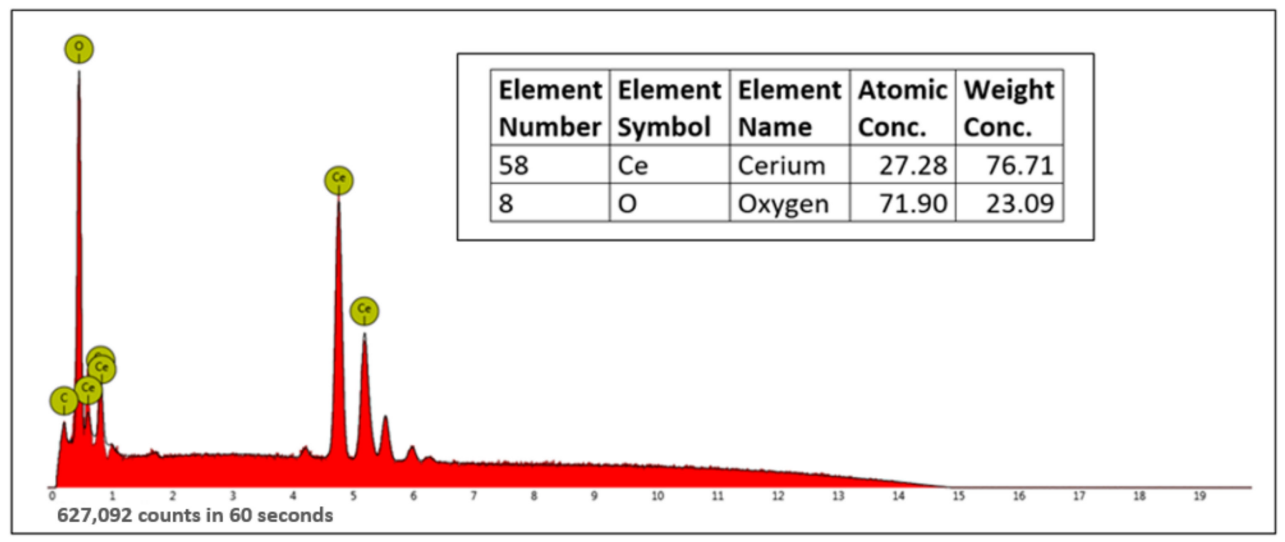

Figure 3. Energy Dispersive X-ray Spectroscopy (EDX) image representing the elemental composition in cerium oxide nanoparticles.

\subsubsection{FTIR Analysis}

The Fourier Transform Infrared spectra generated in the range of $4000-650 \mathrm{~cm}^{-1}$ are shown in the Figure 4. In the functional group region, two intense peaks are found, in which one is the broad peak at $3361.24 \mathrm{~cm}^{-1}$ corresponding to the $\mathrm{OH}$ group, and the other one is the peak at $1556.36 \mathrm{~cm}^{-1}$ representing the $\mathrm{N}-\mathrm{O}$ band because of the presence of nitrate [50]. The peak corresponding to $1556.36 \mathrm{~cm}^{-1}$ represents the $\mathrm{C}-\mathrm{H}$ stretching and the peaks corresponding to $1051.13 \mathrm{~cm}^{-1}$ and $841 \mathrm{~cm}^{-1}$ represent the $\mathrm{C}-\mathrm{O}$ band. In the fingerprint region, the peak corresponding to $658 \mathrm{~cm}^{-1}$ represents the O-Ce-O band thereby confirming the presence of cerium oxide nanoparticles [51]. 


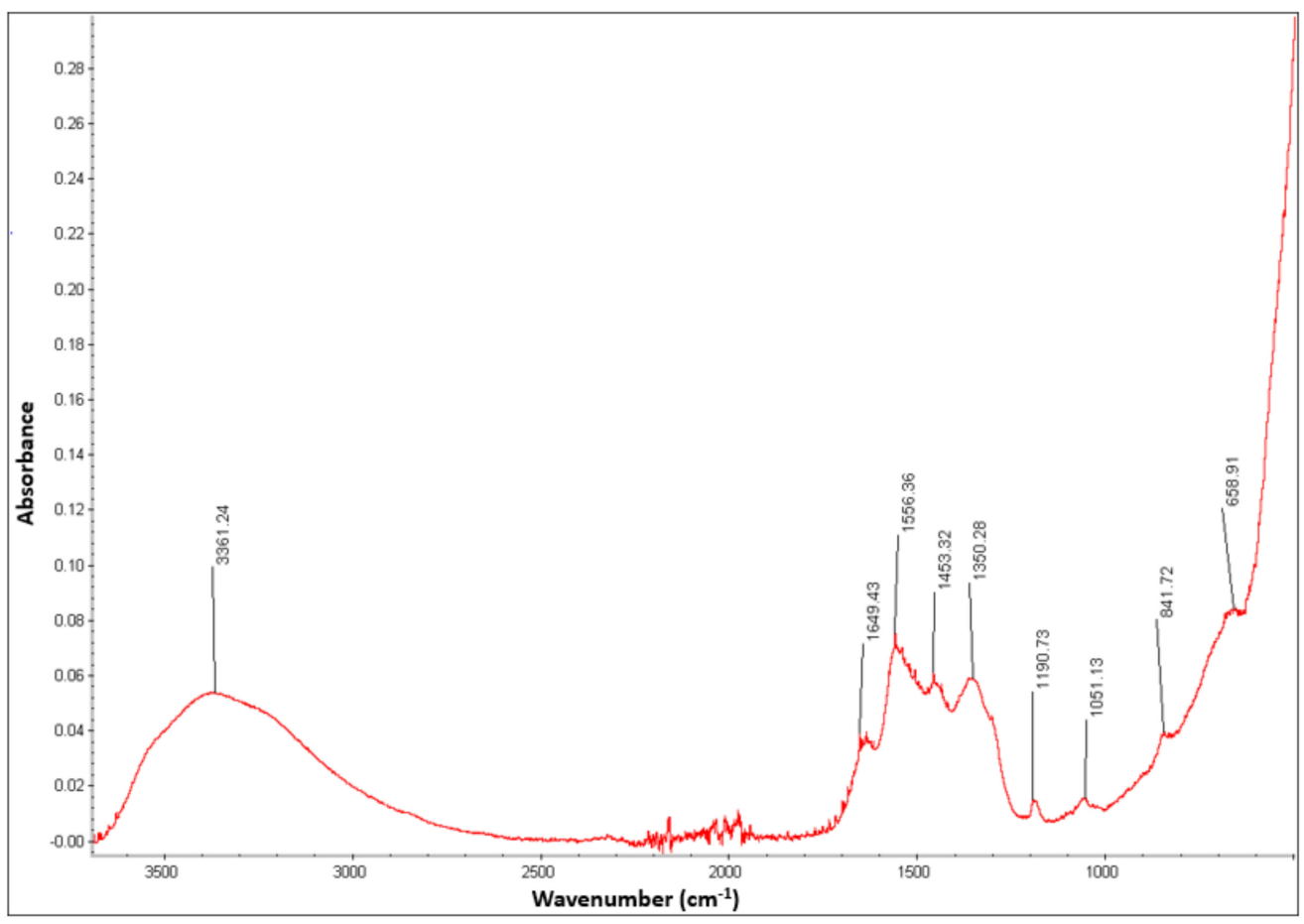

Figure 4. Fourier Transform Infrared Spectroscopy (FTIR) spectrum representing the absorbance spectra of cerium oxide nanoparticles.

\subsubsection{XRD Analysis}

The XRD pattern recorded at the rate of $2 \theta$ per min is shown in the Figure 5 . The peaks at $28.3^{\circ}, 32.9^{\circ}, 47.1^{\circ}, 56.1^{\circ}, 58.7^{\circ}, 69.1^{\circ}, 76.2^{\circ}$, and $78.7^{\circ}$ represent the diffraction peaks corresponding to the crystal planes, $(1,1,1),(2,0,0),(2,2,0),(3,1,1),(2,2,2),(4,0,0),(3,3,1)$, and $(4,2,0)$, respectively. When compared with the standard diffraction pattern of cerium oxide (JCPDS card number 34-0394), the crystal structure of the current sample of cerium oxide was determined to be cubic fluorite structure [52]. No other phases were identified as peaks confirming that pure cerium oxide is obtained with no other impurities. The size of crystal can be determined by broadening of peaks which can further be analyzed by using methods such as Debye-Scherrer method and Williamson-Hall method [53].

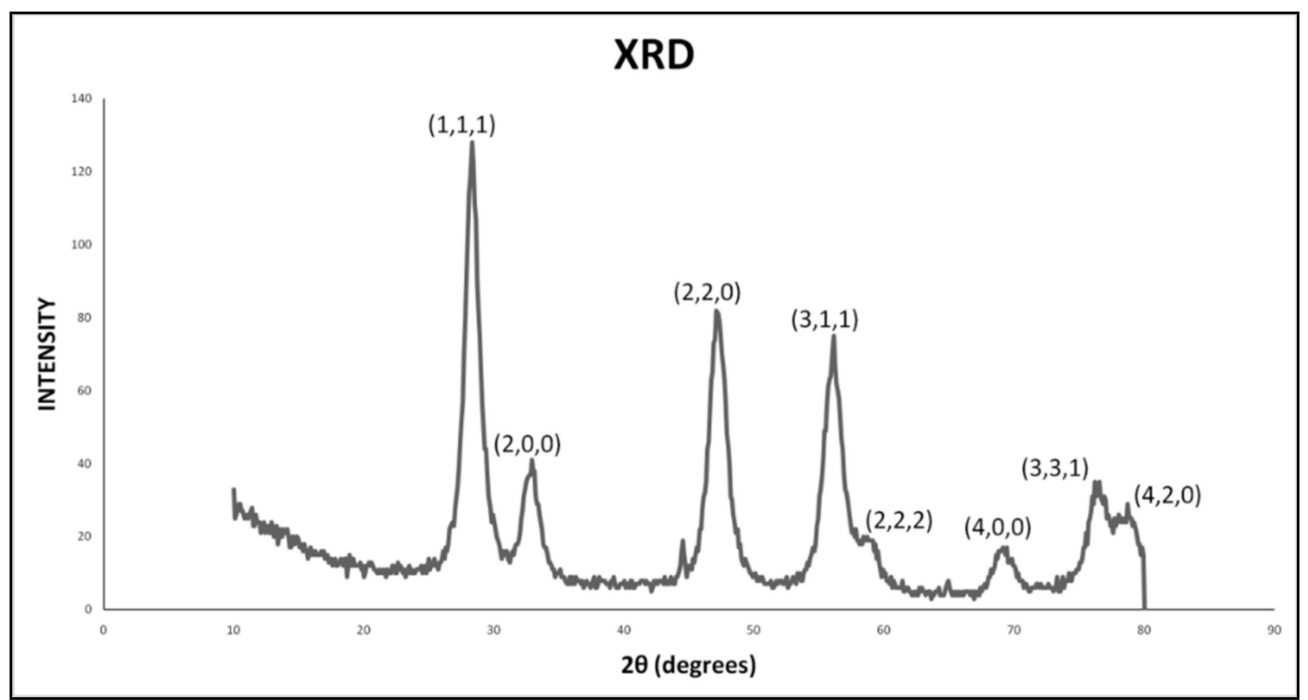

Figure 5. X-ray Diffraction Spectroscopy (XRD) spectrum representing the crystal planes corresponding to the crystal structure of $\mathrm{CeO}_{2}$. 


\subsection{Effect of Cerium Oxide Nanoparticles on Cell Viability and Cytotoxicity}

Cerium oxide nanoparticles have various applications including biomedical, cosmetics, sensors, bio-supercapacitors, etc., further study is necessary to obtain additional information about their toxicological attributes and their probable impact on human health [32].

Beas-2B cells were exposed to different concentrations of cerium oxide nanoparticles for $48 \mathrm{~h}$ and were analyzed for the cell damage using MTT assay. Figure 6 displays the concentration-dependent effects of the cerium oxide nanoparticles produced by hydroxidemediated method on Beas-2B cell viability. The cells were treated with the concentrations of the cerium oxide nanoparticles ranging from 10-100 $\mu \mathrm{g}$ per $100 \mu \mathrm{L}$ for $48 \mathrm{~h}$. Cells with $25 \mu \mathrm{g}$ of SWCNTs were considered as positive control. The cells were treated with SWCNTs showed significant decrease in cell viability compared to the cells with no nanoparticles (negative control). Whereas decrease in the cell viability was not observed in case of the cells treated with $\mathrm{CeO}_{2}$ nanoparticles indicating that the nanoparticles did not exhibit any cytotoxic effect. In fact, the cell viability is better than the negative control in the cells treated with $\mathrm{CeO}_{2}$ nanoparticles. According to several research reports [54,55], the amount of formazan crystals generated is not primarily determined by cell number. The MTT assay is based on mitochondrial succinate dehydrogenases converting the tetrazolium dye to formazan. However, cytosolic enzymes like nicotinamide adenine dinucleotide (NADH) reductase and flavin oxidase may potentially be involved in this process [56]. Furthermore, the rate of formazan conversion has been connected to cellular metabolic activity as well as the number of mitochondria present in the cell. As a result, larger cells with more mitochondria convert tetrazolium at a faster pace [57]. Thus, the apparent rise in the percentage of viable cells seen in Beas-2B cells could be explained by an influence on mitochondrial activity, which is not always associated with increases in cell viability and proliferation.

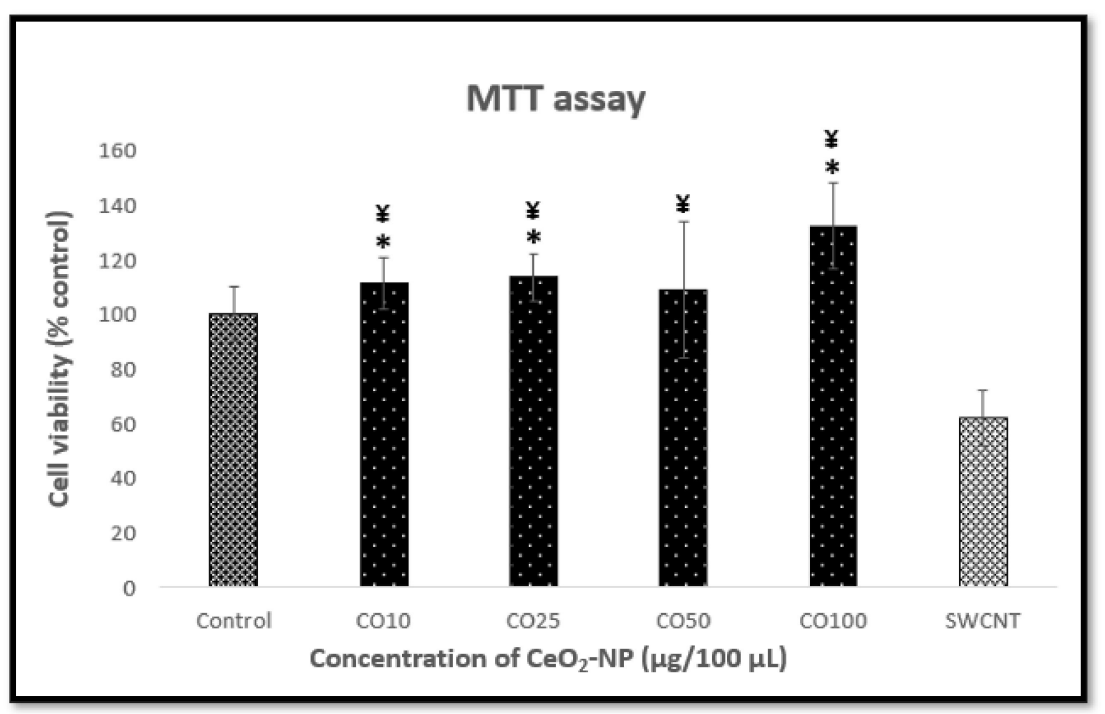

Figure 6. 3-(4,5-Dimethylthiazol-2-yl)-2,5-Diphenyltetrazolium Bromide (MTT) assay of cerium oxide nanoparticles $\left(\mathrm{CeO}_{2}-\mathrm{NP}\right)$. The MTT dye uptake by the Beas-2B cells was read at $570 \mathrm{~nm}$ using spectrophotometer. (Absorbance is mean \pm 8 wells, 6 times experiment was performed independently). $X$-axis: Control—no nanoparticles, $\mathrm{CO} 10-\mathrm{CeO}_{2}-\mathrm{NP}, 10 \mu \mathrm{g}, \mathrm{CO} 25-\mathrm{CeO}_{2}-\mathrm{NP}, 25 \mu \mathrm{g}$, $\mathrm{CO} 50-\mathrm{CeO}_{2}-\mathrm{NP}, 50 \mu \mathrm{g}, \mathrm{CO} 100-\mathrm{CeO}_{2}-\mathrm{NP}, 100 \mu \mathrm{g}$, and SWCNT—Single-wall carbon nanotubes, $25 \mu \mathrm{g}$ per $100 \mu \mathrm{L}$ DMEM. Y-axis: cell viability expressed in \% control. Statistical evaluation of differences was made using the Student $\mathrm{T}$ test at significance levels of $p 0.05$ with respect to control $\left(^{*}\right)$ and SWCNT (¥). Reproduced with permission of [49]. Copyright SPIE conference, 2016.

Statistical evaluation of differences was made using the Student $\mathrm{T}$ test at significance levels of $p 0.05$ with respect to control $\left({ }^{*}\right)$ and SWCNT ( $\left.¥\right)$. Beas-2B cells treated with $10 \mu \mathrm{g}$, $25 \mu \mathrm{g}$, and $100 \mu \mathrm{g}$ of $\mathrm{CeO}_{2}$ nanoparticles showed significant difference with respect to 
negative control (cells with no nanoparticles) and the cells treated with $10 \mu \mathrm{g}, 25 \mu \mathrm{g}, 50 \mu \mathrm{g}$, and $100 \mu \mathrm{g}$ of $\mathrm{CeO}_{2}$ nanoparticles showed significant difference with respect to the cells treated with SWCNTs.

We observed more than $100 \%$ of cells being viable at concentration of $100 \mu \mathrm{g}$ per $100 \mu \mathrm{L}$ $\mathrm{CeO}_{2}$ nanoparticles, which was reconfirmed by Live/Dead cell imaging assay (Figure 7). Images of Live/Dead assay showed no cell death where the Beas-2B cells treated with concentrations of the cerium oxide nanoparticles ranging from 10-100 $\mu$ g. Considerable cell death was observed with the cells treated with SWCNTs for $48 \mathrm{~h}$ as shown in Figure 7. The obtained outcomes were consistent with the MTT assay.
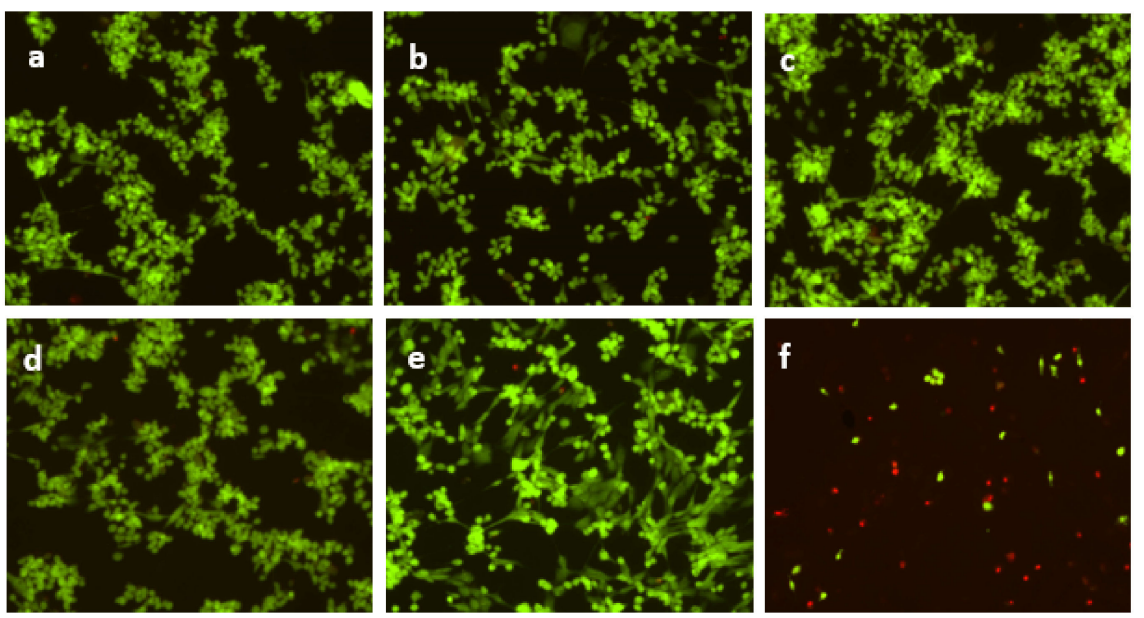

Figure 7. Live/Dead assay of cerium oxide nanoparticles. Images of stained human lung epithelial (Beas-2B) cells in the presence of varying concentration of nanoparticles where (a) Negative control—no nanoparticle; (b) $\mathrm{CeO}_{2}-\mathrm{NP}-10 \mu \mathrm{g}$; (c) $\mathrm{CeO}_{2}-\mathrm{NP}-25 \mu \mathrm{g}$; (d) $\mathrm{CeO}_{2}-\mathrm{NP}-50 \mu$; (e) $\mathrm{CeO}_{2}-\mathrm{NP}-100 \mu \mathrm{g}$; and (f) SWCNTs-25 $\mu \mathrm{g}$ per $100 \mu \mathrm{L}$ DMEM (experiment was performed 6 times independently). Reproduced with permission of [49]. Copyright SPIE conference, 2016.

Previous studies demonstrated selective toxicity of nanoceria towards the cancer and the normal cell lines. Prostate cancer cell lines (PC-3) treated with nanoceria induced toxic effects, whereas non-toxic towards normal mouse fibroblast cell line (L929) which was confirmed by MTT assay [58]. Significantly low levels of cytotoxicity were observed in L929 at the concentrations from 250-500 $\mu \mathrm{g} / \mathrm{mL}$ in MTT assay [59].

\subsection{Effect of Cerium Oxide Nanoparticles on Oxidative Stress}

Reactive oxygen species (ROS) is a collection of oxygen radicals and certain nonradical oxidizing agents, that can be converted easily into radicals [60]. Major site for ROS production is mitochondria in mammalian cells. When cellular production of ROS overpowers its antioxidant capacity, cellular macromolecules for example lipids, protein, and DNA may get damaged. Such an imbalance is called "oxidative stress" which may cause pathogenesis of a several human diseases [61].

The synthesized cerium oxide nanoparticles were tested for its effect on oxidative stress by ROS assay. Results revealed that the nanoparticles did not affect viability of the Beas-2B cells shown by the constancy in nearly all dosages. Our data showed that there was no significant increase in the ROS level formed with 5-100 $\mu$ g of $\mathrm{CeO}_{2}$ nanoparticles and remained same as the negative control till $48 \mathrm{~h}$. Measurement of the intensity of fluorescence was done at excitation and emission of wavelength at 485/527 nm, respectively, and expressed as fluorescence units (Figure 8). No significant difference was observed between the tested/treated cells and the control in a statistical evaluation of differences made using the Student $T$ test at significance levels of $p 0.05$ with respect to control $\left(^{*}\right)$. 


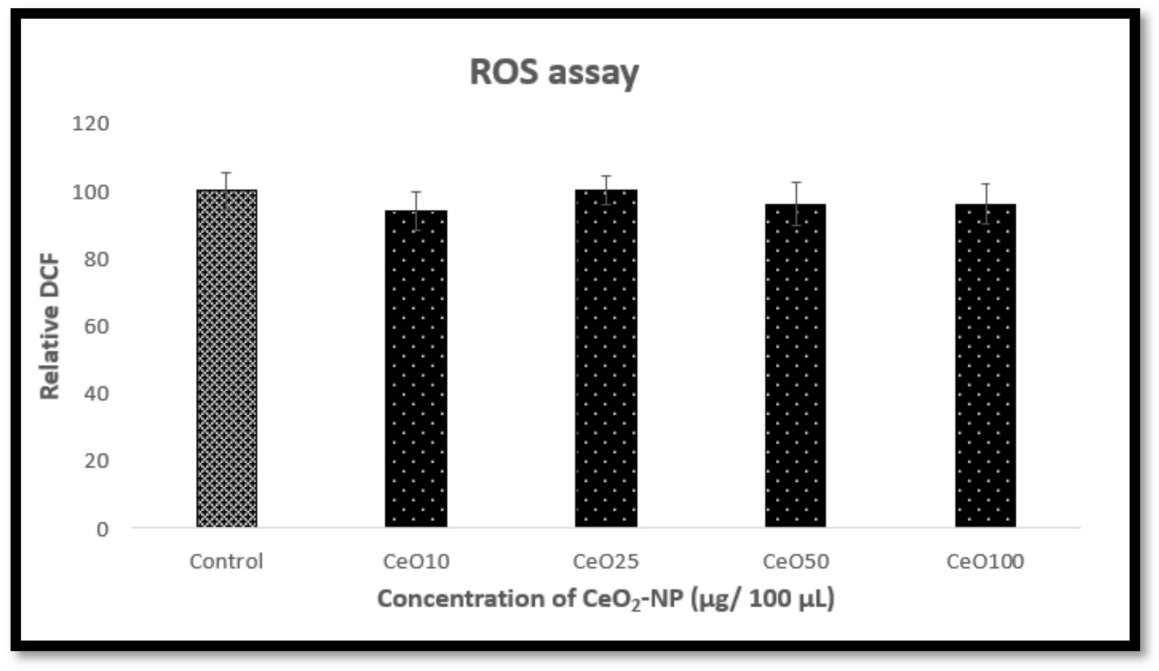

Figure 8. Reactive oxygen species (ROS) assay of cerium oxide nanoparticles. ROS induced by cerium oxide was measured in terms of the intensity of fluorescence at excitation and emission of wavelength at $485 / 527 \mathrm{~nm}$, respectively, and expressed as fluorescence units (Fluorescence is mean \pm 8 wells, 6 times experiment was performed independently). $X$-axis: Control-no nanoparticles, $\mathrm{CO} 10-\mathrm{CeO}_{2}-\mathrm{NP}, 10 \mu \mathrm{g}, \mathrm{CO} 25-\mathrm{CeO}_{2}-\mathrm{NP}, 25 \mu \mathrm{g}, \mathrm{CO} 50-\mathrm{CeO}_{2}-\mathrm{NP}, 50 \mu \mathrm{g}, \mathrm{CO} 100-\mathrm{CeO}_{2}-\mathrm{NP}, 100 \mu \mathrm{g}$, and SWCNT—Single-wall carbon nanotubes, $25 \mu \mathrm{g}$ per $100 \mu \mathrm{L}$ DMEM. Y-axis: cell viability expressed in \% control. Statistical evaluation of differences was made using the Student $\mathrm{T}$ test at significance levels of $p 0.05$ with respect to control $\left.{ }^{*}\right)$. Reproduced with permission of [49]. Copyright SPIE conference, 2016.

Previous studies showed increase in DCF fluorescence intensity in lung adenocarcinoma (A549) cells to $171 \%, 200 \%$, and $259 \%$ after $3 \mathrm{~h}$ and $240 \%, 266 \%$, and $286 \%$ after $6 \mathrm{~h}$ exposure of $25 \mu \mathrm{g} / \mathrm{mL}, 50 \mu \mathrm{g} / \mathrm{mL}$, and $100 \mu \mathrm{g} / \mathrm{mL}$ of $\mathrm{CeO}_{2}$ nanoparticles, respectively, as compared to control. However, ROS production decreased $(115 \%, 118 \%$, and $109 \%$ at $25 \mu \mathrm{g} / \mathrm{mL}, 50 \mu \mathrm{g} / \mathrm{mL}$, and $100 \mu \mathrm{g} / \mathrm{mL}$, respectively) after $24 \mathrm{~h}$ exposure [62].

\section{Conclusions}

The current work discussed the synthesis and characterization of cerium oxide nanoparticles. The $\mathrm{CeO}_{2}$ nanoparticles were successfully synthesized by hydroxide mediated approach and pale-yellow color nanoparticles were obtained. The synthesized nanoparticles were characterized by SEM, FESEM, EDX, FTIR, and XRD. The SEM analysis determined the size of the nanoparticles to be in the range of 10 to $30 \mathrm{~nm}$ and the EDX analysis indicated the elemental composition of the nanoparticles without any other impurities. The FTIR spectra determined the presence of $\mathrm{CeO}_{2}$ nanoparticles. The XRD analysis determined the crystal structure of the nanoparticles. Biocompatibility studies performed using Beas-2B cells in MTT assay, Live/Dead viability assay, and ROS assay showed that the $\mathrm{CeO}_{2}$ nanoparticles are compatible with the cells and there was no cell death even at higher concentrations $(100 \mu \mathrm{g}$ per $100 \mu \mathrm{L})$ of the $\mathrm{CeO}_{2}$ nanoparticles. Thus, $\mathrm{CeO}_{2}$ nanoparticles could be used in various biomedical applications including biosensors and cancer therapy. $\mathrm{CeO}_{2}$ nanomaterials may also be used in filters and ultraviolet absorbers to produce products such as catalytic converters and sunscreen. Furthermore, as $\mathrm{CeO}_{2}$ nanoparticles can cross cell membranes due to their small size, they could be effective for drug delivery.

Author Contributions: Conceptualization, P.P.T. and G.T.R.; Data curation, P.P.T.; Formal analysis, P.P.T., N.K.G. and N.N.B. Methodology, P.P.T. and N.K.G.; Project administration, G.T.R.; Supervision, B.R.L.; Validation, P.P.T; Writing—original draft, P.P.T. and N.K.G.; Writing—review, K.P. and J.C.H.; Writing - editing, P.P.T. All authors have read and agreed to the published version of the manuscript.

Funding: This research received no external funding. 
Institutional Review Board Statement: Not applicable.

Informed Consent Statement: Not applicable.

Acknowledgments: We would like to thank Center for Material Research (CMR) for their support in this project. We also thank Olga Trofimova at Jefferson Lab, Newport News, Virginia for the characterization experiments.

Conflicts of Interest: The authors declare no conflict of interest.

\section{References}

1. Gazzi, A.; Fusco, L.; Orecchioni, M.; Ferrari, S.; Franzoni, G.; Yan, J.S.; Rieckher, M.; Peng, G.; Lucherelli, M.A.; Vacchi, I.A.; et al. Graphene, other carbon nanomaterials and the immune system: Toward nanoimmunity-by-design. J. Phys. Mater. 2020, 3, 034009. [CrossRef]

2. Mai, H.D.; Rafiq, K.; Yoo, H. Nano Metal-Organic Framework-Derived Inorganic Hybrid Nanomaterials: Synthetic Strategies and Applications. Chem. A Eur. J. 2017, 23, 5631-5651. [CrossRef] [PubMed]

3. Dong, L.; Craig, M.M.; Khang, D.; Chen, C. Applications of Nanomaterials in Biology and Medicine. J. Nanotechnol. 2012, 2012, 1-2. [CrossRef]

4. Mukhtar, M.; Bilal, M.; Rahdar, A.; Barani, M.; Arshad, R.; Behl, T.; Brisc, C.; Banica, F.; Bungau, S. Nanomaterials for Diagnosis and Treatment of Brain Cancer: Recent Updates. Chemosensors 2020, 8, 117. [CrossRef]

5. Kamboj, V.K.; Kumar, A.; Hooda, M.S.; Sangwan, P. Nanotechnology: Various methods used for preparation of Nanomaterials. Asian J. Pharm. Pharmacol. 2018, 4, 356-393. [CrossRef]

6. Dimulescu, I.A.; Nechifor, A.C.; Bărdacă, C.; Oprea, O.; Paşcu, D.; Totu, E.; Albu, P.; Nechifor, G.; Bungău, S. Accessible Silver-Iron Oxide Nanoparticles as a Nanomaterial for Supported Liquid Membranes. Nanomaterials 2021, 11, 1204. [CrossRef] [PubMed]

7. Choi, J.Y.; Lee, S.H.; Bin Na, H.; An, K.; Hyeon, T.; Seo, T.S. In vitro cytotoxicity screening of water-dispersible metal oxide nanoparticles in human cell lines. Bioprocess Biosyst. Eng. 2009, 33, 21-30. [CrossRef]

8. Younis, A.; Chu, D.; Li, S.; Younis, A.; Chu, D.; Li, S. Cerium Oxide Nanostructures and Their Applications. In Functionalized Nanomaterials; IntechOpen: London, UK, 2016; Available online: https://www.intechopen.com/chapters/52860 (accessed on 20 August 2021). [CrossRef]

9. Akhtar, K.; Khan, S.A.; Khan, S.B.; Asiri, A.M. Scanning Electron Microscopy: Principle and Applications in Nanomaterials Characterization. In Handbook of Materials Characterization; Springer: Basingstoke, UK, 2018; ISBN 9783319929552.

10. Asati, A.; Santra, S.; Kaittanis, C.; Perez, J.M. Surface-Charge-Dependent Cell Localization and Cytotoxicity of Cerium Oxide Nanoparticles. ACS Nano 2010, 4, 5321-5331. [CrossRef]

11. Zhang, Q.L.; Yang, Z.M.; Ding, B.J. Synthesis of Cerium Oxide Nanoparticles by the Precipitation Method. Mater. Sci. Forum 2009, 610-613, 233-238. [CrossRef]

12. Nyoka, M.; Choonara, Y.E.; Kumar, P.; Kondiah, P.P.D.; Pillay, V. Synthesis of Cerium Oxide Nanoparticles Using Various Methods: Implications for Biomedical Applications. Nanomaterials 2020, 10, 242. [CrossRef] [PubMed]

13. Dhall, A.; Self, W. Cerium Oxide Nanoparticles: A Brief Review of Their Synthesis Methods and Biomedical Applications. Antioxidants 2018, 7, 97. [CrossRef]

14. Xu, C.; Qu, X. Cerium oxide nanoparticle: A remarkably versatile rare earth nanomaterial for biological applications. NPG Asia Mater. 2014, 6, e90. [CrossRef]

15. Thakur, N.; Manna, P.; Das, J. Synthesis and biomedical applications of nanoceria, a redox active nanoparticle. J. Nanobiotechnol. 2019, 17, 1-27. [CrossRef]

16. Heckman, K.L.; DeCoteau, W.; Estevez, A.; Reed, K.J.; Costanzo, W.; Sanford, D.; Leiter, J.C.; Clauss, J.; Knapp, K.; Gomez, C.; et al. Custom Cerium Oxide Nanoparticles Protect against a Free Radical Mediated Autoimmune Degenerative Disease in the Brain. ACS Nano 2013, 7, 10582-10596. [CrossRef] [PubMed]

17. Mourdikoudis, S.; Pallares, R.M.; Thanh, N.T.K. Characterization techniques for nanoparticles: Comparison and complementarity upon studying nanoparticle properties. Nanoscale 2018, 10, 12871-12934. [CrossRef] [PubMed]

18. Baalousha, M.; Ju-Nam, Y.; Cole, P.A.; Gaiser, B.; Fernandes, T.F.; Hriljac, J.A.; Jepson, M.A.; Stone, V.; Tyler, C.R.; Lead, J.R. Characterization of cerium oxide nanoparticles-Part 1: Size measurements. Environ. Toxicol. Chem. 2012, 31, 983-993. [CrossRef] [PubMed]

19. Fu, Q.; Saltsburg, H.; Flytzani-Stephanopoulos, M. Active Nonmetallic Au and Pt Species on Ceria-Based Water-Gas Shift Catalysts. Science 2003, 301, 935-938. [CrossRef] [PubMed]

20. Kaspar, J.; Fornasiero, P.; Graziani, M. Use of CeO2-based oxides in the three-way catalysis. Catal. Today 1999, 50, 285-298. [CrossRef]

21. Sun, C.; Hui, R.; Roller, J. Cathode materials for solid oxide fuel cells: A review. J. Solid State Electrochem. 2010, 14, 1125-1144. [CrossRef]

22. Jasinski, P.; Suzuki, T.; Anderson, H.U. Nanocrystalline undoped ceria oxygen sensor. Sens. Actuators B Chem. 2003, 95, 73-77. [CrossRef] 
23. Feng, X.; Sayle, D.C.; Wang, Z.L.; Paras, M.S.; Santora, B.; Sutorik, A.C.; Sayle, T.X.T.; Yang, Y.; Ding, Y.; Wang, X.; et al. Converting Ceria Polyhedral Nanoparticles into Single-Crystal Nanospheres. Science 2006, 312, 1504. [CrossRef] [PubMed]

24. Yin, X.; Hong, L.; Liu, Z.-L. Oxygen permeation through the LSCO-80/CeO2 asymmetric tubular membrane reactor. J. Membr. Sci. 2006, 268, 2-12. [CrossRef]

25. Ozer, N. Optical Properties and Electrochromic Characterization of Sol-Gel Deposited Ceria Films. Sol. Energy Mater. Sol. Cells 2001, 68, 391-400. [CrossRef]

26. Asati, A.; Santra, S.; Kaittanis, C.; Nath, S.; Perez, J.M. Oxidase-Like Activity of Polymer-Coated Cerium Oxide nanoparticles. Angew. Chem. Int. Ed. 2009, 48, 2308-2312. [CrossRef]

27. Tarnuzzer, R.W.; Colon, J.; Patil, S.; Seal, S.; Cancer, M.D.A.; Healthcare, O.R. Vacancy Engineered Ceria Nanostructures for Protection from Radiation-Induced Cellular Damage. Nano Lett. 2005, 5, 2573-2577. [CrossRef] [PubMed]

28. Kalyanaraman, V.; Naveen, S.V.; Mohana, N.; Balaje, R.M.; Navaneethakrishnan, K.R.; Brabu, B.; Murugan, S.S.; Kumaravel, T.S. Biocompatibility studies on cerium oxide nanoparticles-combined study for local effects, systemic toxicity and genotoxicity via implantation route. Toxicol. Res. 2019, 8, 25-37. [CrossRef]

29. Urner, M.; Schlicker, A.; Z'Graggen, B.R.; Stepuk, A.; Booy, C.; Buehler, K.P.; Limbach, L.; Chmiel, C.; Stark, W.J.; Beck-Schimmer, B. Inflammatory Response of Lung Macrophages and Epithelial Cells after Exposure to Redox Active Nanoparticles: Effect of Solubility and Antioxidant Treatment. Environ. Sci. Technol. 2014, 48, 13960-13968. [CrossRef] [PubMed]

30. Fisichella, M.; Berenguer, F.; Steinmetz, G.; Auffan, M.; Rose, J.; Prat, O. Toxicity evaluation of manufactured CeO2 nanoparticles before and after alteration: Combined physicochemical and whole-genome expression analysis in Caco-2 cells. BMC Genom. 2014, 15, 700. [CrossRef] [PubMed]

31. Franchi, L.P.; Manshian, B.B.; Souza, T.; Soenen, S.; Matsubara, E.Y.; Rosolen, J.M.; Takahashi, C.S. Cyto- and genotoxic effects of metallic nanoparticles in untransformed human fibroblast. Toxicol. Vitr. 2015, 29, 1319-1331. [CrossRef] [PubMed]

32. RajeshKumar, S.; Naik, P. Synthesis and biomedical applications of Cerium oxide nanoparticles-A Review. Biotechnol. Rep. 2018, 17, 1-5. [CrossRef] [PubMed]

33. Pešić, M.; Podolski-Renić, A.; Stojković, S.; Matovic, B.; Zmejkoski, D.; Kojić, V.; Bogdanovic, G.; Pavićević, A.; Mojovic, M.; Savic, A.; et al. Anti-cancer effects of cerium oxide nanoparticles and its intracellular redox activity. Chem. Interact. 2015, 232, 85-93. [CrossRef] [PubMed]

34. Lord, M.S.; Jung, M.; Teoh, W.Y.; Gunawan, C.; Vassie, J.; Amal, R.; Whitelock, J.M. Cellular uptake and reactive oxygen species modulation of cerium oxide nanoparticles in human monocyte cell line U937. Biomaterials 2012, 33, 7915-7924. [CrossRef] [PubMed]

35. Rosenkranz, P.; Fernandez-Cruz, M.L.; Conde, E.; Ramírez-Fernández, M.; Flores, J.C.; Navas, J.M. Effects of cerium oxide nanoparticles to fish and mammalian cell lines: An assessment of cytotoxicity and methodology. Toxicol. Vitr. 2012, 26, 888-896. [CrossRef] [PubMed]

36. Xia, T.; Kovochich, M.; Liong, M.; Mädler, L.; Gilbert, B.; Shi, H.; Yeh, J.I.; Zink, J.I.; Nel, A.E. Comparison of the Mechanism of Toxicity of Zinc Oxide and Cerium Oxide Nanoparticles Based on Dissolution and Oxidative Stress Properties. ACS Nano 2008, 2, 2121-2134. [CrossRef]

37. Ali, M.M.; Mahdi, H.S.; Parveen, A.; Azam, A. Mediated Method Optical properties of cerium oxide (CeO2) nanoparticles synthesized by hydroxide mediated method. In AIP Conference Proceedings; AIP Publishing: Melville, NY, USA, 2018; Volume 1953, p. 030044.

38. Reshma, P. Molecular Nanotechnology Cerium Oxide Nanoparticles: Synthesis, Characterization and Study of Antimicrobial Activity. J. Nanomater. Mol. Nanotechnol. 2017, 6, 1-4. [CrossRef]

39. Tumkur, P.P.; Bayon, N.N.; Gunasekaran, N.K.; Lamani, B.R.; Prabhakaran, K.; Hall, J.C.; Ramesh, G.T. Evaluation of Cellulose Nanoparticles Synthesized by Acid Hydrolysis for Safe Applications. J. Nanosci. Res. Rep. 2020, 2, 1-5. [CrossRef]

40. Mutalib, M.A.; Rahman, M.A.; Othman, M.H.D.; Ismail, A.F.; Jaafar, J. Chapter 9-Scanning Electron Microscopy (SEM) and Energy-Dispersive X-ray (EDX) Spectroscopy. In Membrane Characterization; Elsevier B.V.: Amsterdam, The Netherlands, 2017; ISBN 9780444637765.

41. Baudot, C.; Tan, C.M.; Kong, J.C. FTIR spectroscopy as a tool for nano-material characterization. Infrared Phys. Technol. 2010, 53, 434-438. [CrossRef]

42. Sehar, S.; Naz, I.; Rehman, A.; Sun, W.; Alhewairini, S.S.; Zahid, M.N.; Younis, A. Shape-controlled synthesis of cerium oxide nanoparticles for efficient dye photodegradation and antibacterial activities. Appl. Organomet. Chem. 2021, 35, 1-10. [CrossRef]

43. Han, X.; Na, T.; Wu, T.; Yuan, B.-Z. Human lung epithelial BEAS-2B cells exhibit characteristics of mesenchymal stem cells. PLoS ONE 2020, 15, e0227174. [CrossRef] [PubMed]

44. Tumkur, P.P.; Praful, T.R.; Lamani, B.R.; Bayón, N.N. Enzymatic Synthesis, Characterization and Biocompatibility Studies of Cellulose Nanoparticles from Cotton Fibers. Adv. Nat. Sci. Nanosci. Nanotechnol. 2018, 2, 1-4.

45. Chacon, E.; Acosta, D.; Lemasters, J. Primary Cultures of Cardiac Myocytes as In Vitro Models for Pharmacological and Toxicological Assessments. In In Vitro Methods in Pharmaceutical Research; Academic Press: Cambridge, MA, USA, 1996. ISBN 012163390X.

46. Goornavar, V.; Biradar, S.; Ezeagwu, C.; Ezeagwu, D.; Hall, J.C.; Ramesh, G.T. Toxicity of Raw and Purified Single-Walled Carbon Nanotubes in Rat's Lung Epithelial and Cervical Cancer Cells. J. Nanosci. Nanotechnol. 2015, 15, 2105-2114. [CrossRef] [PubMed]

47. Lopes, V.R.; Sanchez-Martinez, C.; Strømme, M.; Ferraz, N. In vitro biological responses to nanofibrillated cellulose by human dermal, lung and immune cells: Surface chemistry aspect. Part. Fibre Toxicol. 2017, 14, 1-13. [CrossRef] [PubMed] 
48. Hartati, Y.W.; Topkaya, S.N.; Gaffar, S.; Bahti, H.H.; Cetin, A.E. Synthesis and characterization of nanoceria for electrochemical sensing applications. RSC Adv. 2021, 11, 16216-16235. [CrossRef]

49. Tumkur, P.P. Study on toxicity, biocompatibility and antioxidant property of cerium oxide nanoparticles in human lung epithelial cells. In Proceedings of the SPIE BiOS, San Francisco, CA, USA, 2-7 February 2019; Volume 10893. [CrossRef]

50. Chelliah, M.; Rayappan, J.B.B.; Krishnan, U.M. Synthesis and Characterization of Cerium Oxide Nanoparticles by Hydroxide Mediated Approach. J. Appl. Sci. 2012, 12, 1734-1737. [CrossRef]

51. Farahamndjou, M.; Zarinkamar, M.; Firoozabadi, T. Synthesis of Cerium Oxide (CeO(2)) Nanoparticles Using Simple COPrecipitation Method. Rev. Mex. De Física 2016, 62, 496-499.

52. Deori, K.; Gupta, D.; Saha, B.; Awasthi, S.K.; Deka, S. Introducing nanocrystalline CeO2 as heterogeneous environmental friendly catalyst for the aerobic oxidation of para-xylene to terephthalic acid in water. J. Mater. Chem. A 2013, 1, 7091-7099. [CrossRef]

53. Pujar, M.S.; Hunagund, S.M.; Desai, V.R.; Patil, S.; Sidarai, A.H. One-step synthesis and characterizations of cerium oxide nanoparticles in an ambient temperature via Co-precipitation method. In AIP Conference Proceedings; AIP Publishing: Melville, NY, USA, 2018; Volume 1942, p. 050026.

54. Van Tonder, A.; Joubert, A.M.; Cromarty, A.D. Limitations of the 3-(4,5-dimethylthiazol-2-yl)-2,5-diphenyl-2H-tetrazolium bromide (MTT) assay when compared to three commonly used cell enumeration assays. BMC Res. Notes 2015, 8, 47. [CrossRef]

55. Riss, T.L.; Moravec, R.A.; Niles, A.L.; Duellman, S.; Benink, H.A.; Worzella, T.J.; Minor, L. Cell Viability Assays. In Assay Guidance Manual; National Center for Biotechnology Information, U.S. National Library of Medicine: Bethesda, MD, USA, 2004; pp. 1-25.

56. Lü, L.; Zhang, L.; Wai, M.S.M.; Yew, D.T.W.; Xu, J. Exocytosis of MTT formazan could exacerbate cell injury. Toxicol. Vitr. 2012, 26, 636-644. [CrossRef] [PubMed]

57. Jabbar, S.A.; Twentyman, P.R.; Watson, J.V. The MTT assay underestimates the growth inhibitory effects of interferons. Br. J. Cancer 1989, 60, 523-528. [CrossRef] [PubMed]

58. Renu, G.; Rani, V.V.D.; Nair, S.V.; Subramanian, K.R.V.; Lakshmanan, V.K. Development of Cerium Oxide Nanoparticles and Its Cytotoxicity in Prostate Cancer Cells. Adv. Sci. Lett. 2012, 6, 17-25. [CrossRef]

59. Nourmohammadi, E.; Khoshdel-Sarkarizi, H.; Nedaeinia, R.; Sadeghnia, H.R.; Hasanzadeh, L.; Darroudi, M.; Oskuee, R.K. Evaluation of anticancer effects of cerium oxide nanoparticles on mouse fibrosarcoma cell line. J. Cell. Physiol. 2019, 234, 4987-4996. [CrossRef] [PubMed]

60. Bayir, H. Reactive oxygen species. Crit. Care Med. 2005, 33, S498-S501. [CrossRef] [PubMed]

61. Thannickal, V.J.; Fanburg, B.L. Reactive oxygen species in cell signaling. Am. J. Physiol. Lung Cell. Mol. Physiol. 2000, 279, L1005-L1028. [CrossRef]

62. Mittal, S.; Pandey, A.K. Cerium Oxide Nanoparticles Induced Toxicity in Human Lung Cells: Role of ROS Mediated DNA Damage and Apoptosis. BioMed Res. Int. 2014, 1-14. [CrossRef] [PubMed] 